Brit. Heart f., 1969, 31, 52.

\title{
Haemodynamic Studies in High Altitude Pulmonary Oedema
}

\author{
SUJOY B. ROY ${ }^{\star}$, J. S. GULERIA, P. K. KHANNA, S. C. MANCHANDA, \\ J. N. PANDE, AND P. S. SUBBA \\ From All India Institute of Medical Sciences and Directorate General, \\ Armed Forces Medical Services, New Delhi, India
}

The clinical and pathological features of acute pulmonary oedema of high altitudes have been the subject of several recent reports (Houston, 1960; Hultgren et al., 1961 ; Peñaloza, 1962; Arias-Stella and Kruger, 1963; Nayak, Roy, and Narayanan, 1964; Menon, 1965; Singh et al., 1965), but the haemodynamic effects of the illness are not well delineated (Fred et al., 1962; Hultgren et al., 1964). The purpose of this communication is to present data on the circulatory and respiratory parameters observed in (1) 6 subjects with high altitude pulmonary oedema studied at 3658 metres within 24 hours of the onset of the illness, and (2) 3 subjects restudied 5 times after recovery.

\section{SubJeCts AND MethodS}

Clinical History. Cases 1, 2, and 3 (Table I) are residents of Nepal (altitude 1524-2438 m.). They

Received May 8, 1968.

* Visiting Professor, Dalhousie University, Halifax, Nova Scotia, Canada (for reprints). reached a post at $4267 \mathrm{~m}$. between March and June 1967, and acclimatized successfully. On September 25, they had to move up to $5182 \mathrm{~m}$., and after some army exercises (digging trenches, pitching tents) developed acute pulmonary oedema on September 27. Case 4, a plainsman, climbed to $3658 \mathrm{~m}$. in late September 1967, went on up to $4572 \mathrm{~m}$. within the next 24 hours, and on exertion developed acute pulmonary oedema on September 28. Case 5 is a native of Tibet, born and brought up at altitudes of over $4267 \mathrm{~m}$. He came to India in 1965, where he was stationed at a height of $2103 \mathrm{~m}$. In May 1967, he went to $3658 \mathrm{~m}$. where he developed acute pulmonary oedema and was taken to a lower altitude. He returned to $3658 \mathrm{~m}$. on September 19, when within 48 hours he developed acute pulmonary oedema for the second time. Case 6 is a plainsman who had an attack of high altitude pulmonary oedma at $4267 \mathrm{~m}$. in July 1967, for which he was flown to sea-level. He returned to $3658 \mathrm{~m}$. on September 27, and developed pulmonary oedema on September 30.

All initial studies were performed within 24 hours of the onset of the illness at an army general hospital at $3658 \mathrm{~m}$. Because of their previous history of pulmonary oedema, Cases 5 and 6 , on arrival at $3658 \mathrm{~m}$.,

TABLE

CIRCULATORY PARAMETERS IN HIGH

\begin{tabular}{|c|c|c|c|c|c|c|c|c|}
\hline \multirow{2}{*}{ Case No. } & \multirow{2}{*}{ Age (yr.) } & \multirow{2}{*}{$\begin{array}{l}\text { Body surface } \\
\text { area }\left(\mathrm{m} .^{2}\right)\end{array}$} & \multirow{2}{*}{$\underset{\text { rate/min. }}{\text { Heart }}$} & \multirow{2}{*}{$\begin{array}{c}\text { Cardiac output } \\
\text { index } \\
\left(1 . / \mathrm{min} . / \mathrm{m} .{ }^{2}\right)\end{array}$} & \multirow{2}{*}{$\begin{array}{l}\text { Stroke volume } \\
\text { index } \\
\text { (ml./beat } / \mathrm{m} \cdot{ }^{2} \text { ) }\end{array}$} & \multicolumn{3}{|c|}{ Blood volume (ml./m.2) } \\
\hline & & & & & & Total & Central & Pulmonary \\
\hline $\begin{array}{l}1 \\
2 \\
3 \\
4 \\
5 \\
6\end{array}$ & $\begin{array}{l}22 \\
23 \\
38 \\
28 \\
20 \\
26\end{array}$ & $\begin{array}{l}1.60 \\
1.72 \\
1.80 \\
1.70 \\
1.58 \\
1.70\end{array}$ & $\begin{array}{r}125 \\
75 \\
75 \\
96 \\
110 \\
140\end{array}$ & $\begin{array}{l}2.4 \\
4.5 \\
3.2 \\
3.4 \\
3.0 \\
3.5\end{array}$ & $\begin{array}{l}19 \\
60 \\
43 \\
35 \\
27 \\
25\end{array}$ & $\begin{array}{l}3900 \\
4700 \\
3600 \\
2590 \\
2900 \\
4200\end{array}$ & $\begin{array}{l}467 \\
865 \\
880 \\
648 \\
440 \\
518\end{array}$ & $\begin{array}{l}206 \\
410 \\
349 \\
176 \\
155 \\
224\end{array}$ \\
\hline
\end{tabular}


were kept in the wards of the hospital under observation, when they developed frank pulmonary oedema. The remaining 4 subjects had to be brought to the hospital by helicopter. The hospital was centrally heated and patients were studied in the $x$-ray room while lying supine on the $x$-ray table. They were acutely ill and had received one or more doses of intravenous morphine (15 mg.) and frusemide ( $40 \mathrm{mg}$.) before the study. They were also on continuous oxygen inhalation (BLB mask) which was interrupted only for 10 minutes for the collection of expired gases and blood samples. Right heart catheterization was performed by positioning a No. 7 cardiac catheter in the pulmonary artery just beyond the valve. The left atrium was entered by the percutaneous transseptal method, as practised in this laboratory (Roy, Bhatia, and Guleria, 1963). The right femoral artery was cannulated to obtain arterial blood pressures and dye curves. Consecutive dye dilution curves were obtained directly on a polyviso channel through a continuous recording densitometer (Colson) by injecting indocyanine green dye into the main pulmonary artery and then into the left atrium. The difference in the mean transit times of the two resulting curves was taken as pulmonary transit time. The cardiac output was measured from the dilution curves by the formula of Hamilton et al. (1932). The volume of blood between the pulmonary artery and the left atrium was obtained by multiplying the pulmonary mean transit time by the average cardiac output, and this represented the pulmonary blood volume. Similarly, the volume of blood between the pulmonary and the femoral arteries was measured by multiplying the pulmonary artery to femoral artery mean transit time by the average cardiac output, and this gave the central blood volume. Details of the technique have already been reported (Roy, Bhardwaj, and Bhatia, 1965a). The total blood volume was estimated by azovan blue dye (Gibson and Evans, 1937). The intracardiac and femoral arterial pressures were recorded through Statham P23AA strain gauge manometers on a 4-channel single gun photographic system. The baseline for all pressure measurements was taken as half the chest thickness at the second costal cartilage, with the patient supine (Roy, Gadboys, and Dow, 1957). Expired gas was collected for a measured period of 3 minutes in a Haldane bag. Minute ventilation was measured directly from a ventilometer. Arterial blood $p \mathrm{H}, \mathrm{PCO}_{2}$, and $\mathrm{Po}_{2}$ were estimated by Beckman electrode, arterial blood gas by the technique of McNeill and Van Slyke, and expired gas by Roughton-Scholander gas analyser. Case 5 was restudied at $3658 \mathrm{~m}$. after a week and again at sea-level 8 weeks later; Case 3 was restudied twice at sea-level 4 and 8 weeks later, while Case 6 was restudied after 4 weeks at sea-level. Except for the difference in the altitude, repeat studies were performed under identical conditions of room temperature, technique, equipment, and observers.

\section{RESULTS}

Circulatory Parameters (Table I and Fig. 1). The pulmonary arterial (or right ventricular) systolic pressures were moderately raised $(36$ to $54 \mathrm{~mm} . \mathrm{Hg}$ ), and the pulmonary arterial wedge and left atrial and filling pressures of both the ventricles were normal. The cardiac output was low normal in 5 patients, and as 3 of them had tachycardia, their stroke volume was much diminished, below $30 \mathrm{ml}$. per beat per square metre of body surface area. The pulmonary blood volume exceeded $310 \mathrm{ml}$. in 2 subjects.

Respiratory Parameters (Table II). The minute ventilation was generally raised. There was consistent increment in the arterial blood $\mathrm{pH}$ values, with concomitant reduction in the $\mathrm{PCO}_{2}$ values. Arterial blood $\mathrm{PO}_{2}$ was significantly decreased, and there was significant alveolar arterial oxygen tension gradient $(18$ to $30 \mathrm{~mm} . \mathrm{Hg}$ ). Case 5 was also anaemic, with an oxygen capacity of only 13.4 volume per cent (packed cell volume was $30 \%$ ).

Restudy Data (Table III). The pulmonary arterial systolic pressure of Case 6 remained high after 4 weeks. The pulmonary blood volume decreased in Case 3 and increased in Cases 5 and 6. The stroke volumes increased in these 3 , and their arterial blood became fully saturated. The $p \mathrm{H}, \mathrm{PCO}_{2}$, and $\mathrm{PO}_{2}$ values approached normal in Cases 3 and 5.

ALTITUDE PULMONARY OEDEMA

\begin{tabular}{|c|c|c|c|c|c|c|c|c|c|c|c|c|c|}
\hline \multicolumn{14}{|c|}{ Pressures (mm. Hg) } \\
\hline \multicolumn{3}{|c|}{ Right ventricle } & \multicolumn{3}{|c|}{ Pulm. artery } & \multirow{2}{*}{$\begin{array}{c}\frac{\text { Pulm. art. }}{\text { wedge }} \\
\text { Mean }\end{array}$} & \multirow{2}{*}{$\begin{array}{c}\begin{array}{c}\text { Left } \\
\text { atrium }\end{array} \\
\text { Mean }\end{array}$} & \multicolumn{3}{|c|}{ Left ventricle } & \multicolumn{3}{|c|}{ Femoral aytery } \\
\hline Syst. & Diast. & $\begin{array}{l}\text { End } \\
\text { diast. }\end{array}$ & Syst. & Diast. & Mean & & & Syst. & Diast. & $\begin{array}{l}\text { End } \\
\text { diast. }\end{array}$ & Syst. & Diast. & Mean \\
\hline $\begin{array}{l}50 \\
54 \\
34 \\
40 \\
36 \\
42\end{array}$ & $\begin{array}{l}0 \\
0 \\
0 \\
0 \\
0 \\
0\end{array}$ & $\begin{array}{l}5 \\
3 \\
5 \\
2 \\
3 \\
3\end{array}$ & $\begin{array}{l}\frac{48}{34} \\
37 \\
36 \\
\end{array}$ & $\begin{array}{l}\frac{20}{15} \\
16 \\
15 \\
-\end{array}$ & $\begin{array}{l}\frac{30}{22} \\
24 \\
24 \\
-\end{array}$ & $\begin{array}{r}\frac{2}{-} \\
9 \\
-\end{array}$ & $\begin{array}{l}1 \\
5 \\
4 \\
8 \\
2 \\
1\end{array}$ & $\begin{array}{l}120 \\
128 \\
110 \\
112 \\
112 \\
115\end{array}$ & $\begin{array}{l}\mathbf{0} \\
\mathbf{0} \\
\mathbf{0} \\
\mathbf{0} \\
\mathbf{0} \\
\mathbf{0}\end{array}$ & $\begin{array}{l}\mathbf{5} \\
\mathbf{5} \\
\mathbf{5} \\
\mathbf{8} \\
\mathbf{3} \\
\mathbf{5}\end{array}$ & $\begin{array}{l}120 \\
128 \\
110 \\
112 \\
112 \\
115\end{array}$ & $\begin{array}{l}76 \\
70 \\
70 \\
60 \\
60 \\
65\end{array}$ & $\begin{array}{l}95 \\
92 \\
80 \\
80 \\
80 \\
80\end{array}$ \\
\hline
\end{tabular}


TABLE II

RESPIRATORY PARAMETERS IN HIGH ALTITUDE PULMONARY OEDEMA

\begin{tabular}{|c|c|c|c|c|c|c|c|c|c|c|c|c|c|c|c|}
\hline \multirow{3}{*}{$\begin{array}{l}\text { Case } \\
\text { No. }\end{array}$} & & & \multirow{3}{*}{ R.Q. } & \multirow{3}{*}{$\begin{array}{l}\text { Vent./ } \\
\text { perf. } \\
\text { ratio }\end{array}$} & \multirow{3}{*}{$\begin{array}{c}\text { Mean } \\
\text { alveolar } \\
\mathrm{O}_{2} \\
\text { tension }\end{array}$} & \multicolumn{8}{|c|}{ Arterial blood } & \multirow{3}{*}{$\begin{array}{l}\text { Mixed } \\
\text { venous } \\
\text { blood } \\
\mathrm{O}_{2} \text { cont. } \\
\text { (vol. } \% \text { ) }\end{array}$} & \multirow{3}{*}{$\begin{array}{c}\text { Alveolar- } \\
\text { arterial } \\
\mathrm{O}_{2} \\
\text { tension } \\
\text { gradient } \\
\text { (mm. Hg) }\end{array}$} \\
\hline & \multicolumn{2}{|c|}{$\begin{array}{c}\text { Minute vol. } \\
(1 . / \mathrm{min} .)\end{array}$} & & & & $p H$ & $\begin{array}{l}\mathrm{Pco}_{2} \\
(\mathrm{~mm} .\end{array}$ & $\underset{(\mathrm{mm} .}{\mathrm{Po}_{2}}$ & $\stackrel{\mathrm{O}_{2}}{\text { content }}$ & $\mathrm{O}_{2}$ & $\underset{\text { satn }}{\mathrm{O}_{2}}$ & $\mid \underset{(\mathrm{mEq} / \mathrm{l} .)}{\mathrm{HCO}_{3}^{-}}$ & $\begin{array}{c}\text { Base } \\
\text { excess }\end{array}$ & & \\
\hline & BTPS & STPD & & & & & & & & & & & & & \\
\hline $\begin{array}{l}1 \\
2 \\
3 \\
4 \\
5 \\
6\end{array}$ & $\begin{array}{r}11 \cdot 8 \\
8 \cdot 7 \\
13 \cdot 8 \\
12 \cdot 1 \\
14 \cdot 1 \\
15 \cdot 6\end{array}$ & $\begin{array}{l}6 \cdot 5 \\
4 \cdot 9 \\
7 \cdot 1 \\
6 \cdot 6 \\
7 \cdot 2 \\
7 \cdot 9\end{array}$ & $\begin{array}{l}1.16 \\
1.11 \\
0.93 \\
1.75 \\
1.03 \\
0.83\end{array}$ & $\begin{array}{l}2.04 \\
1.04 \\
1.08 \\
0.99 \\
0.81 \\
0.86\end{array}$ & $\begin{array}{l}70 \\
64 \\
65 \\
69 \\
56 \\
60\end{array}$ & $\begin{array}{l}7 \cdot 46 \\
7 \cdot 45 \\
7 \cdot 49 \\
7 \cdot 45 \\
7 \cdot 43 \\
7 \cdot 52\end{array}$ & $\begin{array}{l}24 \\
29 \\
26 \\
34 \\
35 \\
27\end{array}$ & $\begin{array}{l}52 \\
42 \\
40 \\
49 \\
27 \\
30\end{array}$ & $\begin{array}{r}21 \cdot 9 \\
18 \cdot 6 \\
18 \cdot 4 \\
17 \cdot 9 \\
7 \cdot 2 \\
14 \cdot 7\end{array}$ & $\begin{array}{l}25 \cdot 3 \\
23 \cdot 8 \\
23 \cdot 8 \\
21 \cdot 1 \\
13 \cdot 4 \\
22 \cdot 2\end{array}$ & $\begin{array}{l}87 \\
78 \\
78 \\
85 \\
54 \\
66\end{array}$ & $\begin{array}{l}16.6 \\
19.6 \\
19.2 \\
22.5 \\
21.9 \\
21.0\end{array}$ & $\begin{array}{l}-4 \\
-2 \cdot 5 \\
-1 \\
0 \\
-1 \\
0\end{array}$ & $\begin{array}{r}17 \cdot 1 \\
15 \cdot 5 \\
14 \cdot 9 \\
15 \cdot 7 \\
4 \cdot 1 \\
11 \cdot 5\end{array}$ & $\begin{array}{l}18 \\
22 \\
25 \\
20 \\
29 \\
30\end{array}$ \\
\hline
\end{tabular}

\section{Discussion}

To evaluate the present findings, the major haemodynamic parameters of the 5 subjects studied by Fred et al. (1962) and Hultgren et al. (1964) are grouped with our observations, and shown in Table IV and Fig. 2. The partial oxygen tension of the arterial blood was not estimated in the previous studies, but the arterial oxygen saturations of 64 to 76 per cent recorded in 3 of their patients are within the range of our observation of 54 to 86 per cent. The heart rate of the 4 subjects studied by Hultgren et al. exceeded 105 beats a minute, 81 in Fred et al.'s patient, whereas the rate in 3 of our patients was below 100, and in 1 the rate reached as high as 140 a minute. Cardiac output index data, available only in 3 subjects, were between 2.5 and $3.01 . / \mathrm{min} . / \mathrm{m} .{ }^{2}$, similar to the output index observed in 3 of our subjects. However, in the remaining 3 , the value was within our normal range of 3.5 to $4.51 . / \mathrm{min} . / \mathrm{m} .^{2}$ Because of tachycardia, the stroke volume index of the 3 subjects was low, similar to the values obtained by Hultgren et al.; the remaining 3 had normal values. Hultgren and coworkers (1964) had emphasized the occurrence of severe pulmonary arterial hypertension in high altitude pulmonary oedema, but in their own subjects, only one patient had severe increase in the pulmonary arterial pressure, and in the remaining 3 the pressure was only moderately raised. The subject studied by Fred et al. had a pulmonary arterial systolic pressure of $68 \mathrm{~mm} . \mathrm{Hg}$. In the present series all the patients had moderate increases in pulmonary arterial pressure ranging from 34 to $48 \mathrm{~mm}$. $\mathrm{Hg}$ systolic. It thus appears that an increase in the pulmonary arterial pressure in high altitude pulmonary oedema

TABLE RESTUDY OF PHYSIO-

\begin{tabular}{|c|c|c|c|c|c|c|c|c|}
\hline \multirow{2}{*}{$\begin{array}{l}\text { Case } \\
\text { No. }\end{array}$} & \multirow{2}{*}{$\begin{array}{c}\text { Date } \\
\text { in } 1967\end{array}$} & \multirow{2}{*}{$\begin{array}{l}\text { Altitude } \\
\text { (metres) }\end{array}$} & \multirow{2}{*}{$\begin{array}{c}\text { Heart } \\
\text { rate/min. }\end{array}$} & \multirow{2}{*}{$\begin{array}{c}\text { Cardiac output } \\
\text { index } \\
\left(1 . / \mathrm{min} . / \mathrm{m} .{ }^{2}\right)\end{array}$} & \multirow{2}{*}{$\begin{array}{c}\text { Stroke volume } \\
\text { index } \\
\left(\mathrm{ml} . / \text { beat } / \mathrm{m} .{ }^{2}\right)\end{array}$} & \multicolumn{3}{|c|}{$\begin{array}{l}\text { Blood volume } \\
\left(\mathrm{ml} . / \mathrm{m}^{2}\right)\end{array}$} \\
\hline & & & & & & Total & Central & Pulmonary \\
\hline \multirow{3}{*}{3} & 28 Sept. & 3658 & 75 & $3 \cdot 2$ & 43 & 3600 & 880 & 349 \\
\hline & 28 Oct. & 198 & 65 & $3 \cdot 2$ & 49 & 4900 & - & - \\
\hline & 20 Nov. & 198 & 60 & $3 \cdot 4$ & 57 & 3400 & 646 & 233 \\
\hline \multirow{3}{*}{5} & 22 Sept. & 3658 & 110 & $3 \cdot 0$ & 27 & 2900 & 440 & 155 \\
\hline & 30 Sept. & 3658 & 80 & $4 \cdot 7$ & 59 & 2500 & 714 & - \\
\hline & 20 Nov. & 198 & 75 & $4 \cdot 3$ & 57 & 3600 & 925 & 423 \\
\hline \multirow{2}{*}{6} & 30 Sept. & 3658 & 140 & $3 \cdot 5$ & 25 & 4200 & 518 & 224 \\
\hline & 27 Oct. & 198 & 120 & $4 \cdot 5$ & 38 & 3800 & 685 & 325 \\
\hline \multicolumn{2}{|c|}{ Normal average } & 198 & 85 & $4 \cdot 1$ & 49 & 3000 & 960 & 210 \\
\hline
\end{tabular}




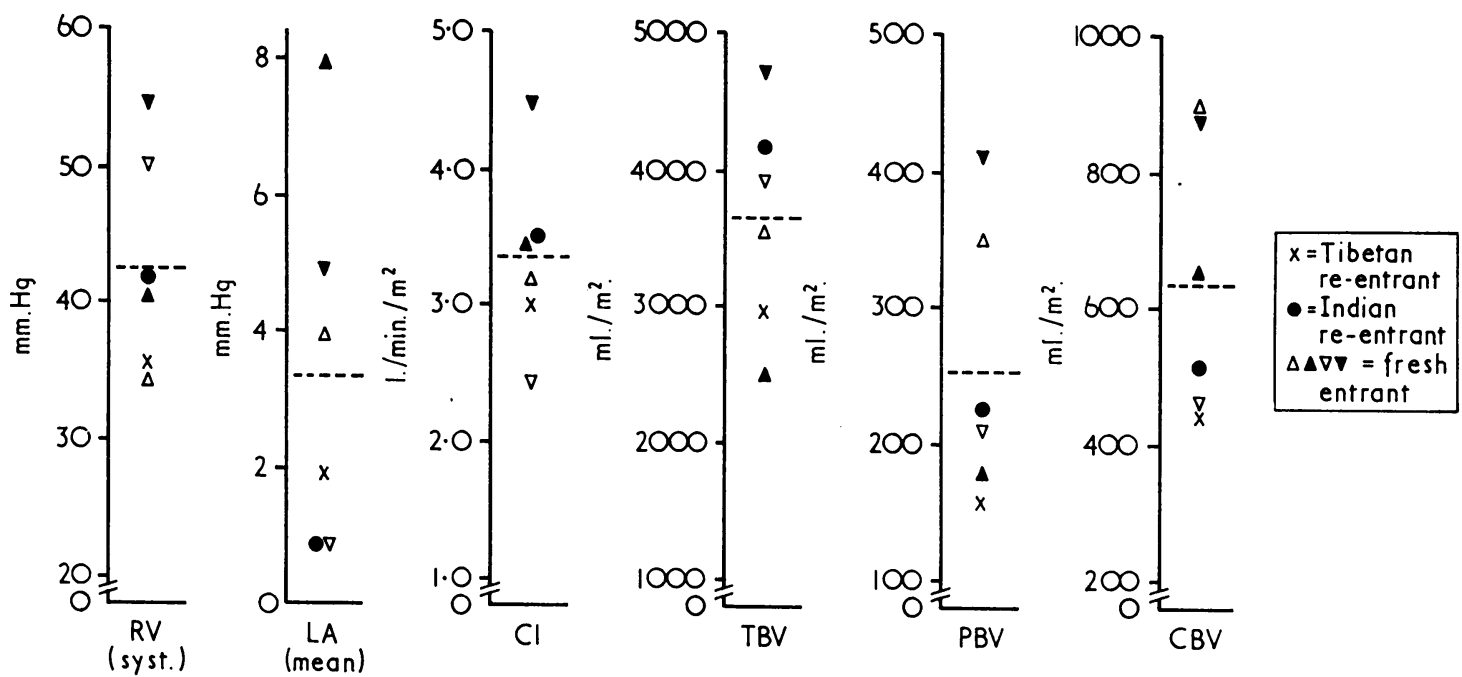

FIg. 1.-Circulatory parameters in 6 subjects with high altitude pulmonary oedema. The Tibetan re-entrant is Case 5, the Indian re-entrant is Case $6 . \quad \nabla=$ Case $1 ; \nabla=$ Case $2 ; \Delta=$ Case $3 ; \Delta=$ Case $4 . \quad R V=$ right ventricular; LA = left atrial; $\mathrm{CI}=$ cardiac index; TBV, PBV, and CBV are total, pulmonary, and central blood volume, respectively. The horizontal broken line in each panel represents the average of the six observed values.

is a constant observation, but a severe degree of hypertension is not a common finding.

Fred et al. could not obtain a pulmonary artery wedge pressure but recorded a normal left atrial pressure in the single patient they studied, whereas Hultgren et al. did not catheterize the left heart and obtained normal to low pulmonary arterial wedge pressures in their 4 patients. So far simul- taneous pulmonary arterial wedge and left atrial pressures have not been measured in patients with high altitude pulmonary oedema. This was done in 3 subjects in the present study, and both mean pressures were found to be the same. The left atrial mean pressure in the 6 subjects was between 1 to $8 \mathrm{~mm}$. $\mathrm{Hg}$, which is within our normal range of 2 to $11 \mathrm{~mm}$. $\mathrm{Hg}$ (average $4 \mathrm{~mm}$. $\mathrm{Hg}$ ) obtained by

III

LOGICAL PARAMETERS

\begin{tabular}{|c|c|c|c|c|c|c|c|c|c|c|c|c|}
\hline \multicolumn{5}{|c|}{ Pressures (mm. Hg) } & \multirow{3}{*}{$\begin{array}{c}\text { Min. vol. } \\
\text { (l./min.) } \\
\text { STPD }\end{array}$} & \multirow{3}{*}{ R.Q. } & \multirow{3}{*}{$\begin{array}{l}\text { Vent./ } \\
\text { perf. } \\
\text { ratio }\end{array}$} & \multirow{3}{*}{$\begin{array}{c}\text { Mean } \\
\text { alveolar } \\
\mathrm{O}_{2} \\
\text { tension }\end{array}$} & \multirow{2}{*}{\multicolumn{4}{|c|}{ Arterial blood }} \\
\hline \multicolumn{3}{|c|}{ Right ventricle } & \multirow{2}{*}{$\begin{array}{c}\begin{array}{c}\text { Left } \\
\text { atrium }\end{array} \\
\text { Mean }\end{array}$} & \multirow{2}{*}{$\begin{array}{c}\begin{array}{c}\text { Femoral } \\
\text { artery }\end{array} \\
\begin{array}{c}\text { Syst. } \\
\text { diast. } \\
\text { mean }\end{array} \\
\end{array}$} & & & & & & & & \\
\hline Syst. & Diast. & $\begin{array}{l}\text { End- } \\
\text { diast. }\end{array}$ & & & & & & & $p \mathrm{H}$ & $\begin{array}{c}\mathrm{PCO}_{2} \\
\underset{\mathrm{Hg}}{\mathrm{mm}}\end{array}$ & $\underset{\underset{\mathrm{Hg}}{\mathrm{Po}_{2}}}{\mathrm{Po}_{\mathbf{m}}}$ & $\begin{array}{c}\mathbf{O}_{\mathbf{2}} \\
\mathbf{s a t n} \\
(\%)\end{array}$ \\
\hline 34 & 0 & 5 & 4 & $\begin{array}{c}110 / 70 \\
(80)\end{array}$ & $7 \cdot 1$ & 0.93 & 1.08 & 65 & $7 \cdot 49$ & 26 & 40 & 78 \\
\hline 27 & 0 & 6 & 6 & $\begin{array}{l}130 / 70 \\
138)\end{array}$ & $7 \cdot 7$ & $0 \cdot 74$ & 0.71 & 96 & $7 \cdot 44$ & 37 & 57 & 89 \\
\hline 25 & 2 & 5 & 7 & $\begin{array}{c}130 / 72 \\
(88)\end{array}$ & $8 \cdot 1$ & 0.74 & 0.67 & 94 & $7 \cdot 42$ & 39 & 70 & 93 \\
\hline 36 & 0 & 3 & 2 & $112 / 60$ & $7 \cdot 2$ & $1 \cdot 03$ & 0.81 & 56 & $7 \cdot 43$ & 35 & 27 & 54 \\
\hline 40 & 0 & 4 & 4 & $118 / 60$ & $8 \cdot 4$ & 1.02 & 1.09 & 66 & $7 \cdot 44$ & 26 & 56 & 89 \\
\hline 33 & 0 & 5 & 8 & $\begin{array}{c}130 / 68 \\
(90)\end{array}$ & - & $1 \cdot 18$ & $1 \cdot 10$ & 107 & $7 \cdot 38$ & 39 & 90 & 97 \\
\hline 42 & 0 & 3 & 1 & $\begin{array}{l}115 / 65 \\
(80)\end{array}$ & $7 \cdot 9$ & $0 \cdot 83$ & $0 \cdot 86$ & 60 & $7 \cdot 52$ & 27 & 30 & 66 \\
\hline 42 & 0 & 3 & 8 & $\begin{array}{c}138 / 68 \\
(90)\end{array}$ & $6 \cdot 3$ & 0.87 & 0.58 & 106 & $7 \cdot 48$ & 34 & 70 & 94 \\
\hline 21 & 0 & 3.5 & 4 & $\begin{array}{c}120 / 70 \\
(85)\end{array}$ & $5 \cdot 4$ & 0.79 & 0.67 & 95 & $7 \cdot 41$ & 39 & 87 & 96 \\
\hline
\end{tabular}




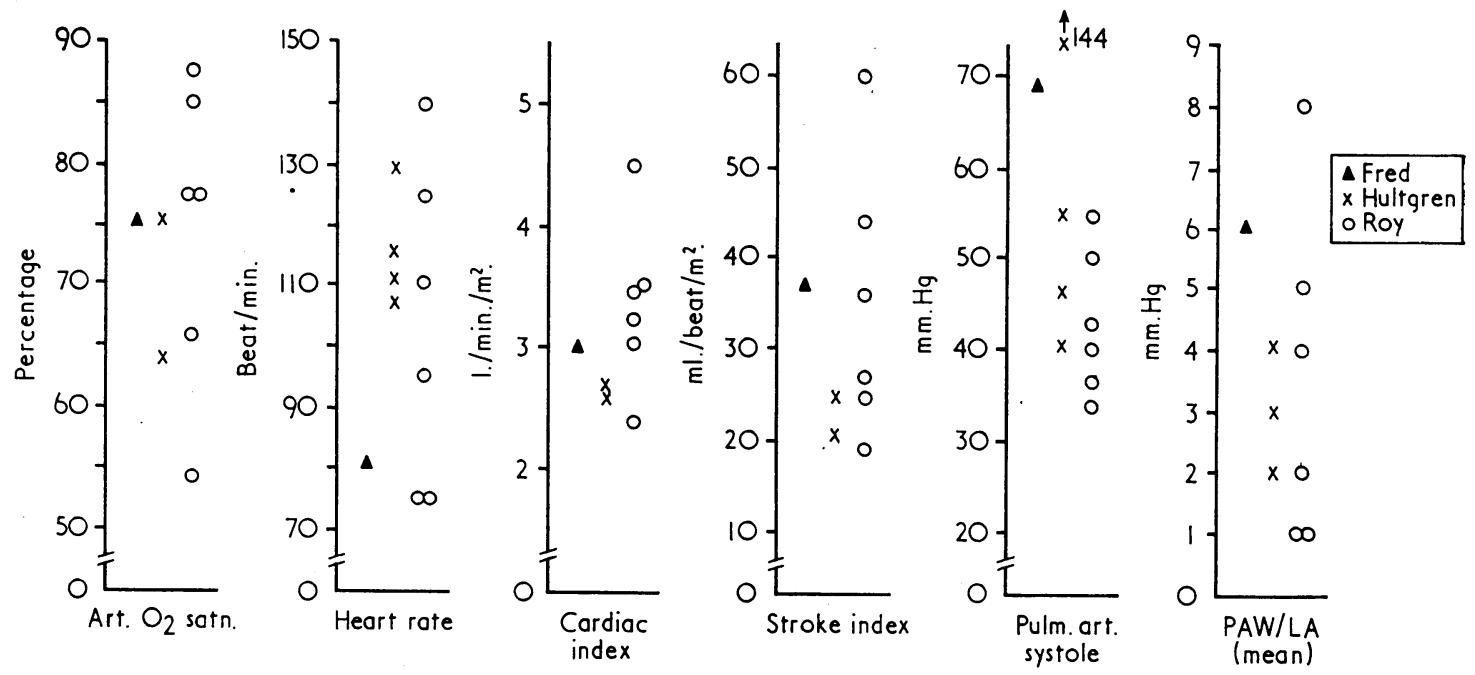

FIG. 2.-Comparison of the main haemodynamic data in 6 subjects with high altitude pulmonary oedema, with the findings in 5 subjects studied by Fred et al. (1962) and Hultgren et al. (1964). Pulmonary arterial pressures were obtained in only 4 subjects, hence right ventricular systolic pressures have been substituted for comparison.

TABLE IV

COMPARISON OF HAEMODYNAMIC DATA IN 11 SUBJECTS WITH ACUTE PULMONARY OEDEMA OF HIGH ALTITUDE

\begin{tabular}{|c|c|c|c|}
\hline Parameters & $\begin{array}{l}\text { Fred et al. }(1962) \\
\quad(1 \text { subject) }\end{array}$ & $\begin{array}{c}\text { Hultgren et al. (1964) } \\
\text { (4 subjects) }\end{array}$ & Roy et al. (present paper) \\
\hline $\begin{array}{l}\text { Arterial } \mathrm{O}_{2} \text { saturation }(\%) \\
\text { Heart rate/min. } \\
\text { Cardiac output index } \\
\quad(1 . / \text { min./m.2) } \\
\text { Stroke volume index } \\
\left.\quad \text { (ml./beat/m. }{ }^{2}\right) \\
\text { Pulmonary artery } \\
\quad \text { (systolic) (mm. } \mathrm{Hg}) \\
\text { Pulmonary artery wedge or } \\
\text { left atrium (mean) (mm. } \mathrm{Hg})\end{array}$ & $\begin{array}{l}76 \\
81 \\
3 \cdot 0 \\
37 \\
68 \\
6\end{array}$ & $\begin{array}{l}76 ; 64 ; ? \\
129 ; 107 ; 115 ; 110 \\
2 \cdot 6 ; 2 \cdot 7 \\
20 ; 25 \\
144 ; 55 ; 47 ; 41 \\
4 ; 2 ; 5 ; 3\end{array}$ & $\begin{array}{l}87 ; 78 ; 78 ; 85 ; 54 ; 66 \\
125 ; 75 ; 75 ; 96 ; 110 ; 140 \\
2 \cdot 4 ; 4 \cdot 5 ; 3 \cdot 2 ; 3 \cdot 4 ; 3 \cdot 0 ; 3 \cdot 5 \\
19 ; 60 ; 43 ; 35 ; 27 ; 25 \\
48 ; 54 \star ; 34 ; 37 ; 36 ; 42^{\star} \\
1 ; 5 ; 4 ; 8 ; 2 ; 1\end{array}$ \\
\hline
\end{tabular}

$\star$ Right ventricular systolic.

studying 25 healthy soldiers (Roy et al., 1967). The restudy left atrial pressure values showed consistent increase $(4-7,2-8$, and $1-8 \mathrm{~mm}$. $\mathrm{Hg}$ ) in the 3 subjects. Hultgren et al. (1964) also noted a similar rise in the pulmonary arterial wedge pressures when restudied subsequently. The present observations confirm those of Fred et al. and Hultgren et al. that pulmonary oedema of high altitude is not due to an increase in the pulmonary capillary or left atrial pressures.

Because the pulmonary blood volume estimated in convalescents from high altitude pulmonary oedema was found to be higher than in those convalescing from high altitude pulmonary hypertension (Roy et al., 1965b), and because there was an 80 per cent increase in the pulmonary blood volume in healthy soldiers when air-lifted from sea-level to $3658 \mathrm{~m}$. within 48 to 72 hours of their arrival, a vulnerable period for high altitude pulmonary oedema (Roy et al., 1968), it was surmised that the pulmonary blood volume grossly increased during high altitude pulmonary oedema (Roy, 1966). The present findings did not support this assumption, for the pulmonary blood volume exceeded the upper limit of our normal value of $310 \mathrm{ml} . / \mathrm{m}^{2}$ (Roy et al., 1967) in only 2 subjects (Cases 2 and 3). There are two possible explanations for this. (1) The technique employed in the present study to measure the pulmonary blood volume estimates only the intravascular blood volume, and fluid which has already oozed out into the alveolar spaces is not accounted for. (2) The patients were acutely ill and had 
received one or more doses of intravenous morphine and frusemide, and it has been shown previously that morphine reduces the pulmonary blood volume (Roy et al., 1965c). This is supported indirectly by the restudy data of Cases 5 and 6 in which the pulmonary blood volume increased considerably 4 to 8 weeks after the episode of oedema.

The total blood volume in 4 subjects exceeded the average normal values, but on restudy variable changes were seen. However, there was evidence of peripheral venous constriction. The average value of the forearm venous distensibility measured plethysmographically (Wood and Eckstein, 1958) in the pulmonary oedema subjects was only $2.8 \mathrm{ml}$. $/ 100$ $\mathrm{ml}$. forearm tissue, as against $4.4 \mathrm{ml} .100 \mathrm{ml}$. in healthy subjects. Similar peripheral venous constriction and shift of the blood volume to the pulmonary circuit, with no change in the total blood volume, were also observed in healthy persons in the first 48 to 72 hours after their arrival by air at an altitude of $3658 \mathrm{~m}$. (Roy et al., 1968). The minute ventilation at BTPS was greatly increased, and even when converted to STPD it was still higher than average normal values, indicating hyperventilation. Added to this, was evidence of respiratory alkalosis (high $p \mathrm{H}$ and low $\mathrm{Pco}_{2}$ ). It is difficult to outline the sequence of events leading to high altitude pulmonary oedema. A possible mechanism may be the sudden accentuation of hypoxia due to a change in altitude, and/or exercise causing hyperventilation and respiratory alkalosis, raised pulmonary arterial pressure, and a shift of the blood volume from the periphery to the pulmonary circuit. It is also possible that hypoxia causes pulmonary capillary endothelial damage which, together with the increased pulmonary arterial pressure and blood volume, leads to pulmonary oedema of high altitude.

\section{SUMMARY}

Data on the circulatory and respiratory parameters of 6 subjects with high altitude pulmonary oedema studied at $3658 \mathrm{~m}$. within 24 hours of the onset of the illness and of 3 subjects restudied after recovery are given. The pulmonary arterial pressure was raised in all subjects, but the pulmonary capillary, left atrial, and filling pressures of both the ventricles were normal. The cardiac output was reduced or normal despite tachycardia in 3 subjects. The pulmonary blood volume exceeded the upper limit of normal values in only 2 subjects, and the probable explanations for the discrepancy are outlined. It is postulated that the rapid accentuation of hypoxia causing a rise in pulmonary arterial pressure, marked peripheral vasoconstric- tion shifting the blood volume to the pulmonary circuit, and damaged pulmonary capillary endothelial lining, may be a possible mechanism of acute pulmonary oedema of high altitude.

The authors are grateful to General A. K. Dev, Professor K. L. Wig, Lt. Col. K. C. Saksena, and Lt. Col. J. S. Sandhu, without whose active co-operation this study would not have been possible. They also wish to thank Professor J. E. Wood, for the plethysmographic study, and Dr. J. R. Talwar, Dr. V. S. Kaushik, and Messrs. Pershad, Sharma, Singh, and Dumre for their technical assistance under difficult and trying conditions.

\section{REFERENCES}

Arias-Stella, J., and Kruger, H. (1963). Pathology of high altitude pulmonary edema. Arch. Path., 76, 147.

Fred, H. L., Schmidt, A. M., Bates, T., and Hecht, H. H. (1962). Acute pulmonary edema of altitude. Clinical and physiologic observations. Circulation, 25, 929.

Gibson, J. G., II, and Evans, W. A., Jr. (1937). Clinical studies of the blood volume. I. Clinical application of a method employing the azo dye "Evans Blue" and the spectrophotometer. f. clin. Invest., 16, 301.

Hamilton, W. F., Moore, J. W., Kinsman, J. M., and Spurling, R. G. (1932). Studies on the circulation. IV. Further analysis of the injection method, and of changes in hemodynamics under physiological and pathological conditions. Amer. F. Physiol., 99, 534.

Houston, C. S. (1960). Acute pulmonary edema of high altitude. New Engl. F. Med., 263, 478.

Hultgren, H. N., Lopez, C. E., Lundberg, E., and Miller, H. (1964). Physiologic studies of pulmonary edema at high altitude. Circulation, 29, 393.

—, Spickard, W. B., Hellriegel, K., and Houston, C. S. (1961). High altitude pulmonary edema. Medicine (Baltimore), 40, 289.

Menon, N. D. (1965). High-altitude pulmonary edema. New Engl. f. Med., 273, 66.

Nayak, N. C., Roy, S., and Narayanan, T. K. (1964). Pathologic features of altitude sickness. Amer. F. Path., 45, 381.

Peñaloza, D. (1962). In Panel discussion: Pulmonary edema at high altitude. Med. thorac. (Basel), 19, 505.

Roy, S. B. (1966). Editorial: Pulmonary blood volume and high altitude pulmonary oedema. Indian Heart $\mathcal{F} ., 18$, 203.

—, Bhardwaj, P., and Bhatia, M. L. (1965a). Pulmonary blood volume in mitral stenosis. Brit. med. F., 2, 1466. , Bhatia, M. L., Gadhoke, S., and Bhatiani, S. K. (1967). Effects of two years' intermittent stay at high altitude on the pulmonary blood volume in man. Brit. Heart f., 29, 428.

$\longrightarrow,-$, and Guleria, J. S. (1963). Percutaneous transseptal left heart catheterization. Indian Heart f., 15, 255.

-, Singh, I., and Khanna, P. K. (1965b). Pulmonary blood volume in high altitude pulmonary oedema. In Symposium on Problems of High Altitude. Armed Forces Medical College, Poona 16th-19th February, p. 49.

, Gadboys, H. L., and Dow, J. W. (1957). Base line for left heart catheterization. Amer. Heart f., 54, 753.

—, Guleria, J. S., Khanna, P. K., Talwar, J. R., Manchanda, S. C., Pande, J. N., Kaushik, V. S., Subba, P. S., and Wood, J.E. (1968). Immediate circulatory response 
to high altitude hypoxia in man. Nature (Lond.), 217, 1177.

Singh, I., Bhatia, M. L., and Khanna, P. K. (1965c). Effect of morphine on pulmonary blood volume in convalescents from high altitude pulmonary oedema. Brit. Heart $\mathcal{F}$., 27, 876.

Singh, I., Kapila, C. C., Khanna, P. K., Nanda, R. B., and
Rao, B. D.P. (1965). High-altitude pulmonary oedema. Lancet, 1, 229.

Wood, J. E., and Eckstein, J. W. (1958). A tandem forearm plethysmograph for study of acute responses of the peripheral veins of man: The effect of environmental and local temperature change, and the effect of pooling blood in the extremities. $\mathcal{F}$. clin. Invest., 37, 41. 